\title{
HUBUNGAN PENGETAHUAN, SIKAP DAN PERILAKU IBU TERHADAP KEBIASAAN MENYIKAT GIGI ANAK
}

\section{KATA KUNCI \\ Pengetahuan, Sikap \\ Perilaku, Menyikat Gigi.}

\author{
Hanim Khalida Zia*, Nurhamidah ${ }^{* *}$, Dhona Afriza ${ }^{* * *}$ \\ *Mahasiswa, FKG, Universitas Baiturrahmah, Padang \\ **Bagian Periodonsia, FKG, Universitas Baiturrahmah, Padang \\ ***Bagian Penyakit Mulut, FKG, Universitas Baiturrahmah, Padang
}

\begin{abstract}
ABSTRAK
Peran orang tua terutama ibu, sangat berpengaruh dalam pemeliharaan kesehatan dan kebersihan gigi anak. Pengetahuan, sikap dan perilaku ibu terhadap kesehatan gigi akan menentukan status kesehatan gigi anak kelak. Tujuan penelitian ini untuk mengetahui hubungan antara pengetahuan, sikap dan perilaku ibu terhadap kebiasaan menyikat gigi pada murid kelas 1 di SDN 02 Ulak Karang Kota Padang. Jenis penelitian adalah survei analitik dengan rancangan cross sectional. Cara pengambilan sampel dengan conservative sampling yaitu 36 orang ibu beserta anaknya.

Hasil penelitian menunjukkan 52,8\% murid kelas 1 SDN 02 Ulak Karang Kota Padang sering menyikat gigi, sedangkan 47,2\% lagi jarang menyikat gigi. Terdapat hubungan signifikan antara pengetahuan ibu dengan kebiasaan menyikat gigi anaknya $(p=0,000)$. Antara perilaku ibu dengan kebiasaan menyikat gigi anaknya juga memiliki hubungan signifikan $(\mathrm{p}=0,007)$. Namun tidak terdapat hubungan antara sikap ibu dengan kebiasaan menyikat gigi anaknya $(\mathrm{p}$ $=0,101)$. Dari hasil penelitian sebagian besar responden sudah mengetahui cara memelihara kesehatan gigi dan mulut anak, aplikasinya dalam hal tindakan pemeliharaan juga sudah baik, tetapi sikap yang ditunjukkan responden dalam pemeliharaan kesehatan gigi dan mulut anak masih kurang.
\end{abstract}

\section{PENDAHULUAN}

Kesehatan gigi merupakan bagian dari kesehatan tubuh yang tidak dapat dipisahkan satu dengan yang lainnya, sebab kesehatan gigi akan mempengaruhi kesehatan tubuh. Pemeliharaan kebersihan gigi merupakan salah satu upaya dalam meningkatkan kesehatan gigi. Secara umum, seseorang dikatakan sehat bukan hanya tubuhnya yang sehat melainkan juga sehat rongga mulut dan giginya. Oleh karena itu, kesehatan gigi sangat berperan dalam menunjang kesehatan tubuh seseorang. ${ }^{1,2}$
Menurut Organisasi Kesehatan Dunia (WHO), 90\% anak-anak mengalami beragam masalah gigi berlubang. Namun, hampir semua permasalahan gigi dapat dicegah, bila didukung dengan kebiasaan menyikat gigi yang benar dan teratur. Kebiasaan menyikat gigi yang benar tentunya dapat menunjang kesehatan gigi menjadi lebih baik. ${ }^{3}$

Beberapa negara berkembang melaporkan sudah ada perbaikan atau peningkatan kesehatan gigi, akan tetapi masalah kesehatan gigi tetap merupakan masalah kesehatan masyarakat pada umumnya. Penyakit gigi merupakan penyakit yang rata- 
rata masih menjadi keluhan bagi masyarakat Indonesia. Menurut Survei Kesehatan Rumah Tangga (SKRT, 2001) penyakit gigi merupakan penyakit tertinggi keenam yang dikeluhkan oleh masyarakat Indonesia. Namun, perilaku masyarakat Indonesia di dalam menjaga kesehatan gigi masih rendah. ${ }^{2}$ Fankari (2004), melaporkan bahwa penyebab timbulnya masalah kesehatan gigi dan mulut pada masyarakat salah satunya adalah faktor perilaku atau sikap mengabaikan kebersihan gigi dan mulut. Hal tersebut dilandasi oleh kurangnya pengetahuan akan pentingnya pemeliharaan gigi dan mulut. Anak masih sangat tergantung pada orang dewasa dalam hal menjaga kebersihan dan kesehatan gigi karena kurangnya pengetahuan anak mengenai kesehatan gigi dibanding orang dewasa. ${ }^{4}$

Pendidikan kesehatan gigi harus diperkenalkan sedini mungkin kepada anak agar mereka dapat mengetahui bagaimana cara memelihara kesehatan gigi secara baik dan benar. Peran orang tua terutama ibu, sangat berpengaruh dalam pemeliharaan kesehatan dan kebersihan gigi anak. Pengetahuan, sikap dan perilaku ibu yang merupakan orang terdekat dengan anak dalam pemeliharaan kesehatan memberikan pengaruh yang sangat signifikan terhadap pengetahuan, sikap dan perilaku anak.,

Pengetahuan orang tua dapat diperoleh secara alami maupun secara terencana yaitu melalui proses pendidikan. Orang tua dengan pengetahuan rendah mengenai kesehatan gigi merupakan faktor predisposisi dari perilaku yang tidak mendukung kesehatan gigi anak. Pengetahuan, sikap dan perilaku ibu terhadap kesehatan gigi akan menentukan status kesehatan gigi anak kelak. Pengetahuan saja tidak cukup, perlu diikuti dengan sikap peduli dan bertindak. Mulai tumbuhnya gigi merupakan proses penting dari pertumbuhan seorang anak. ${ }^{1,3}$

Seorang ibu sudah seharusnya mempunyai pengetahuan, sikap dan perilaku yang baik terhadap kesehatan gigi dan mulut agar dapat memberikan pendidikan kesehatan rongga mulut (oral health education) kepada anak. Hasil penelitian Suryawati, dkk di Kecamatan Ciputat dan Kecamatan Pasar minggu menunjukkkan bahwa $76,8 \%$ ibu memiliki pengetahuan yang kurang terhadap kesehatan gigi anak, 84,1\% memiliki sikap yang baik, dan $89 \%$ memiliki perilaku yang kurang dalam usaha pemeliharaan kesehatan gigi anak. ${ }^{7}$

Berdasarkan di atas peneliti merasa tertarik untuk mengetahui hubungan pengetahuan, sikap dan perilaku ibu terhadap kebiasaan menyikat gigi pada murid kelas 1 di SDN 02 Ulak Karang Kota Padang. SDN 02 Ulak Karang berada di tengah kota, lingkungan ini menyebabkan terdapatnya keragaman tingkat pendidikan pada ibu-ibu yang tentu saja akan mempengaruhi pengetahuan ibu mengenai kesehatan gigi, dengan begitu hal ini juga akan mempengaruhi sikap dan perilaku 
kesehatannya dalam memelihara kesehatan dan kebersihan gigi anaknya.

\section{METODE PENELITIAN}

Jenis penelitian ini adalah penelitian survei analitik dengan rancangan cross sectional. Populasi adalah ibu beserta anaknya yang duduk di kelas 1 SDN 02 Ulak Karang Kota Padang. Populasi subjek penelitian adalah 36 orang ibu beserta anaknya yang menjadi murid kelas 1 di SDN 02 Ulak Karang Kota Padang. Teknik pengambilan sampel adalah conservative sampling.

Dalam penelitian ini, peneliti menggunakan 2 buah kuesioner sebagai alat bantu untuk melakukan wawancara pada subjek penelitian. Satu kuesioner diberikan kepada ibu dan satunya lagi langsung ditanyakan pada murid kelas 1 di SDN 02 Ulak Karang
Kota Padang dengan sistem kuesioner terpimpin. Adapun kuesioner yang diberikan mempunyai tipe pertanyaan tertutup. Data yang diperoleh selanjutnya dianalisis dengan uji Chi square dengan menggunakan program SPSS.

\section{HASIL PENELITIAN}

Berdasarkan cara kerja yang telah dilakukan oleh peneliti, maka didapatkan skor rata-rata untuk pengetahuan ibu sebesar 54, sikap ibu sebesar 48, dan perilaku ibu sebesar 52. Pengetahuan, sikap dan perilaku ibu dikatakan baik bila jumlah skor jawaban di atas rata-rata dan dikatakan kurang bila jumlah skor jawaban di bawah rata-rata. Kebiasaan menyikat gigi anak dikatakan sering yaitu $2 \mathrm{x}$ sehari/lebih dan dikatakan jarang yaitu sekali 2 hari atau tidak tiap hari.

Tabel 1. Distribusi Responden menurut Pengetahuan Ibu dan Kebiasaan Menyikat Gigi Anak

\begin{tabular}{|c|c|c|c|c|c|c|c|c|}
\hline \multicolumn{8}{|c|}{ Pengetahuan ibu } & \multirow{3}{*}{$\begin{array}{c}\begin{array}{c}\mathrm{P} \\
\text { value }\end{array} \\
0,000\end{array}$} \\
\hline $\begin{array}{c}\text { Kebiasaan } \\
\text { menyikat gigi }\end{array}$ & \multicolumn{2}{|c|}{ Baik } & \multicolumn{2}{|c|}{ Kurang } & \multicolumn{2}{|c|}{ Total } & \multirow{2}{*}{$\begin{array}{l}\text { OR } \\
17,5\end{array}$} & \\
\hline & $\mathrm{N}$ & $\%$ & $\mathrm{~N}$ & $\%$ & $\mathrm{~N}$ & $\%$ & & \\
\hline Sering & 15 & 83,3 & 3 & 16,7 & 18 & 100 & & \\
\hline Jarang & 4 & 22,2 & 14 & 77,8 & 18 & 100 & & \\
\hline Jumlah & 19 & 52,8 & 17 & 47,2 & 36 & 100 & & \\
\hline
\end{tabular}

Tabel 2. Distribusi Responden menurut Sikap Ibu dan Kebiasaan Menyikat Gigi Anak

\begin{tabular}{ccccccccc}
\hline \multicolumn{1}{c}{ Sikap ibu } & & & & & \\
\hline $\begin{array}{c}\text { Kebiasaan } \\
\begin{array}{c}\text { menyikat gigi } \\
\text { anak }\end{array}\end{array}$ & Baik & Kurang & Total & OR & $\begin{array}{c}\mathrm{P} \\
\text { value }\end{array}$ \\
\hline Sering & $\mathrm{N}$ & $\%$ & $\mathrm{~N}$ & $\%$ & $\mathrm{~N}$ & $\%$ & 3,095 & 0,191 \\
Jarang & 13 & 65 & 7 & 35 & 20 & 100 & & \\
Jumlah & 6 & 37,5 & 10 & 62,5 & 16 & 100 & & \\
\hline
\end{tabular}


Tabel 3. Distribusi Responden menurut Perilaku Ibu dan Kebiasaan Menyikat Gigi Anak

\begin{tabular}{ccccccccc}
\hline \multicolumn{1}{c}{ Perilaku ibu } \\
\hline $\begin{array}{c}\text { Kebiasaan } \\
\text { menyikat gigi anak }\end{array}$ & Baik & Kurang & Total & OR & $\begin{array}{c}\text { P } \\
\text { value }\end{array}$ \\
\hline & $\mathrm{N}$ & $\%$ & $\mathrm{~N}$ & $\%$ & $\mathrm{~N}$ & $\%$ & 7,042 & 0,008 \\
\hline Sering & 13 & 76,5 & 4 & 23,5 & 17 & 100 & & \\
Jarang & 6 & 31,6 & 13 & 68,4 & 19 & 100 & & \\
\hline Jumlah & 19 & 52,8 & 17 & 47,2 & 36 & 100 & & \\
\hline
\end{tabular}

\section{PEMBAHASAN}

Hasil analisis hubungan pengetahuan ibu terhadap kebiasaan menyikat gigi anak diperoleh bahwa ada sebanyak 15 dari 18 $(83,3 \%)$ ibu dengan pengetahuan baik memiliki anak yang sering menyikat gigi. Sedangkan ibu dengan pengetahuan kurang, ada 4 dari $18(22,2 \%)$ memiliki anak yang sering menyikat gigi. Hasil uji statistic diperoleh nilai $\mathrm{p}=0,000$ maka dapat disimpulkan ada perbedaan proporsi kejadian memiliki anak yang sering menyikat gigi antara ibu yang pengetahuannya baik dengan ibu yang pengetahuannya kurang (ada hubungan yang signifikan antara pengetahuan ibu dengan kebiasaan menyikat gigi anak). Dari hasil analisis diperoleh pula nilai $\mathrm{OR}=17,5$, artinya ibu dengan pengetahuan baik mempunyai peluang 17,5 kali memiliki anak yang sering menyikat gigi dibandingkan ibu dengan pengetahuan kurang.

Hasil analisis hubungan sikap ibu terhadap kebiasaan menyikat gigi anak diperoleh bahwa ada sebanyak 13 dari 20 (65\%) ibu dengan sikap baik memiliki anak yang sering menyikat gigi. Sedangkan ibu dengan sikap kurang, ada 6 dari 16 (37,5\%) memiliki anak yang sering menyikat gigi. Hasil uji statistic diperoleh nilai $\mathrm{p}=0,191$ maka dapat disimpulkan tidak ada perbedaan proporsi kejadian memiliki anak yang sering menyikat gigi antara ibu yang sikapnya baik dengan ibu yang sikapnya kurang (tidak ada hubungan yang signifikan antara sikap ibu dengan kebiasaan menyikat gigi anak). Dari hasil analisis diperoleh pula nilai OR = 3,095, artinya ibu dengan sikap baik hanya mempunyai peluang 3,095 kali memiliki anak yang sering menyikat gigi dibandingkan ibu dengan sikap kurang.

Hasil analisis hubungan perilaku ibu terhadap kebiasaan menyikat gigi anak diperoleh bahwa ada sebanyak 13 dari 17 (76,5\%) ibu dengan perilaku baik memiliki anak yang sering menyikat gigi. Sedangkan ibu dengan perilaku kurang, ada 6 dari 19 $(31,6 \%)$ memiliki anak yang sering menyikat gigi. Hasil uji statistik diperoleh nilai $\mathrm{p}=$ 0,008 maka dapat disimpulkan ada perbedaan proporsi kejadian memiliki anak yang sering menyikat gigi antara ibu yang perilakunya baik dengan ibu yang perilakunya kurang (ada hubungan yang signifikan antara perilaku ibu dengan kebiasaan menyikat gigi anak). Dari hasil analisis diperoleh pula nilai $\mathrm{OR}=7,042$, artinya ibu dengan perilaku baik mempunyai peluang 7,042 kali memiliki 
anak yang sering menyikat gigi dibandingkan ibu dengan perilaku kurang.

Dalam penelitian ini, pengetahuan dan perilaku responden yang baik belum sesuai dengan sikapnya. Sikap ibu masih kurang dalam hal pemberian pasta gigi saat menyikat gigi pada anak setelah usia 2 tahun dan pemberian makanan dan minuman manis diluar jam makan. Hal ini sama seperti pada penelitian Suryawaty, dkk di Kecamatan Ciputat dan Kecamatan Pasar Minggu yang menunjukkan bahwa pengetahuan dan perilaku ibu mengenai kesehatan gigi dan mulut anak sudah baik akan tetapi sikap ibu masih sangat kurang dalam memelihara kesehatan gigi dan mulut anaknya.

\section{KESIMPULAN}

Hasil penelitian menunjukkan 52,8\% murid kelas 1 SDN 02 Ulak Karang Kota Padang sering menyikat gigi, sedangkan $47,2 \%$ lagi jarang menyikat gigi. Terdapat hubungan yang signifikan antara pengetahuan ibu dengan kebiasaan menyikat gigi pada anaknya $(\mathrm{p}=0,000)$. Hubungan antara perilaku ibu dengan kebiasaan menyikat gigi anaknya juga memiliki hubungan yang signifikan $(p=0,008)$. Namun tidak terdapat hubungan antara sikap ibu dengan kebiasaan menyikat gigi anaknya $(\mathrm{p}=0,191)$.

Dalam penelitian ini sebagian besar responden sudah mengetahui cara memelihara kesehatan gigi dan mulut anak, aplikasinya dalam hal tindakan pemeliharaan juga sudah baik, akan tetapi sikap yang ditunjukkan responden dalam pemeliharaan kesehatan gigi dan mulut anak masih banyak yang kurang.

\section{SARAN}

Dengan demikian diharapkan adanya program penyuluhan dari pihak terkait secara berkala dan berkesinambungan terutama kepada ibu-ibu tentang pentingnya memelihara kesehatan gigi dan mulut anak sejak usia dini. SDN 02 Ulak Karang sebaiknya juga memberikan pendidikan pada anak-anak tentang pentingnya menyikat gigi. Selain itu, orang tua juga harus berperan aktif dalam membiasakan anak melakukan penyikatan gigi secara teratur sejak dini dan membawa anak kedokter gigi untuk melakukan pemeriksaan gigi secara rutin.

\section{DAFTAR PUSTAKA}

1. Riyanti, E, Pengenalan dan Perawatan Kesehatan Gigi Anak Sejak Dini, 2005. http:/www.dechacare.com/: 25 November 2011.

2. Sondang, P.; Hamada, T. Menuju Gigi dan Mulut Sehat. Medan: USU Press, 2008, 415.

3. PDGI, Mengajak Anak untuk Selalu Menyikat Gigi, 2009. http://sikatgigipagimalam.com/: $\quad 26$ November 2011.

4. Fankari. Pengaruh Penyuluhan dengan Metode Stimulasi dan Demonstrasi terhadap Perubahan Perilaku Menjaga Kesehatan Gigi dan Mulut Anak Sekolah Dasar. Karya Tulis Ilmiah DIV. Perawat Pendidik UGM, 2004.

5. Pertiwi, A.S, Gambaran Pola Karies Gigi Permanen Ditinjau dari Dental Neglect Siswa Kelas 5-6 SDN Cikudayasa 2 Kecamatan Cileunyi Bandung. Jurnal Kedokteran Gigi Anak. Bandung: Bagian Kedokteran Gigi anak FKG Unpad.2008. 
6. PDGI, Inisiatif Kesehatan Gigi dan Mulut, Paradigma Sehat, 2009. http://pdgionline.com/: 26 November 2011.

7. Suryawati, S.; Tantur, S.; Handayani, T.; Resmisari, T.; Wahyuni, S, Gigi Berlubang atau Karies Gigi pada Balita, 2009. http://stetoskopmerah.blogspot.com/: $\quad 26$ November 2011. 